9. Information on the Package Travel Directive in connection with the COVID-19. URL: https://ec.europa.eu/info/sites/default/files/coronavirus info_ptd_19.3.2020.pdf.

10. Tourism and transport package. 13 May 2020. URL: https://ec.europa.eu/commission/presscorner/detail/en/QANDA_20_870.

11. Coronavirus. Cancellation of travel packages and the balancing of remedies to keep the tourism industry alive in Italy and France. De Berti Jacchia Franchini Forlani Studio Legale (2020, April, 14). URL: https://www.dejalex.com/wp-content/uploads/2020/04/ArticoloCoronavirus-Tourism.pdf.

\title{
DOI https://doi.org/10.30525/978-9934-26-179-4-12
}

\section{ОЦІНОЧНІ ПОНЯТТЯ ЯК ЕЛЕМЕНТ МЕХАНІЗМУ ЦИВІЛЬНО-ПРАВОВОГО РЕГУЛЮВАННЯ}

\author{
Гелецька I. O. \\ кандидат юридичних наук, заступник директора з навчальної, \\ наукової роботи та міжнародного співробітництва \\ Галииький коледж імені В'ячеслава Чорновола \\ м. Тернопіль, Украӥна
}

Баб’юк М. П.

кандидат юридичних наук, директор

Галииький коледж імені В'ячеслава Чорновола

м. Тернопіль, Украӥна

Сьогодні важко уявити сучасне цивільне право без певного масиву понять та категорій. Аби у цих поняттях не заплутатися, суб'єкти права погоджуються, аби кожне 3 них характеризувалося певним набором ознак, що дозволяють вирізняти його з поміж інших цивільно-правових понять. У цьому контексті ми говоримо про визначеність цивільноправових норм. Але ступінь визначеності цивільно-правових понять різна: у нормах цивільного права зустрічаються абсолютно-визначені та відносно-визначені поняття. У абсолютно-визначених наявні усі ознаки тих явищ, які ними позначаються (юридична особа, правочин, договір тощо). У відносно-визначених, навпаки, відсутня достатня кількість загальних ознак. В тексті цивільно-правових законів досить поширені такі категорії як розумність, справедливість, добросовісність, 
поважні причини, достатня підстава, значне поліпшення, зловмисна домовленість, цінне майно, необхідні витрати, надзвичайна обставина, істотне значення тощо. Популярність подібних універсальних категорій пояснюється не лише особливим диспозитивним методом цивільноправового регулювання, але і тим, що створення певних зразків, здатних підлаштовуватися під різні життєві ситуації, $є$ одним із способів впливу правового регулювання в цілому на суспільні відносини. Мова іде про такі елементи сучасного законодавства як оціночні поняття. Це визнаний прийом законодавчої техніки за допомогою якого досягається можливість індивідуального підходу до кожної справи, і який дає можливість зменшити обсяги нормативноправового масиву та спростити його.

Оціночне поняття - певний лаконічно сформульований у законі стандарт, 3 яким особа при здійсненні цивільного права має співставляти свою поведінку i, водночас певна абстракція, що не може бути визначена чіткими межами, іiі зміст не встановлює вимог до здійснення конкретних дій суб'єктом права. Як зазначав професор М. Бару [1, с. 104] - «це особливий спосіб вираження волі законодавця, що створює передумови для зближення правотворчої та правозастосовчої діяльності».

Оціночні поняття це складна багатоцільова система, за допомогою якої вирішуються конкретні завдання у сфері правового регулювання статики та динаміки цивільного обігу. Крім того, ця система представляє собою взаємопов'язану та взаємообумовлену сукупність цивільно-правових оціночних норм, які в рамках підсистем речових та зобов'язальних правовідносин впливають на суспільні відносини, що ними регулюються. Разом 3 тим, регулятивний вплив усіх елементів системи підпорядковано єдиній меті - гармонізації прав та законних інтересів особи, що дозволяє вести мову про їх системну та функціональну єдність. Тому наявність у законі оціночних понять, хоча i створює передумови для ідентичних судових оцінок неоднакових життєвих ситуацій, все ж $є$ кращим, ніж наявність у законі чітко викладеного змістового шаблону.

Оскільки у цивільному праві оціночні поняття використовуються не лише як засіб правотворчої діяльності, ай інтерпретаційної техніки, то зміст функцій оціночних понять у цивільному праві обумовлено тим, на якій стадії правового регулювання вони реалізуються. Якщо це стадія правотворчості, то з їх допомогою забезпечується гнучкість правового регулювання, узгодженість із моральними нормами, законодавча економія. На стадії ж правозастосування, зміст функцій пов'язаний із забезпеченням індивідуального регулювання. 
Процес пізнання цивільно-правової норми $з$ оціночним поняттям представляє собою складне комплексне явище, що структурно складається з двох пов'язаних між собою процесів - тлумачення та конкретизація. Конкретизація і тлумачення оціночних понять у прав явища об'єктивні, властиві правовому регулюванню, нетотожні, але багато у чому володіють спільними рисами та складним характером співвідношення та взаємовпливу.

На думку Богдановича С.П., конкретизація оцінюваного поняття - це об'єктивно обумовлений процес розвитку та деталізації абстрактних, формально-невизначених правових норм, у яких виражається максимальна визначеність та повнота суті змісту оціночних понять по відношенню до учасників конкретних цивільних правовідносин [2, с. 19].

Тлумачення правової норми 3 оціночним поняттям представляє собою діяльність, яка характеризується певною специфікою:

- по-перше, така діяльність має бути пов'язана з інтерпретацією не лише нормативно-правових актів, але і інших підзаконних актів;

- по-друге, вона виступає необхідною умовою правового регулювання майнових відносин;

- по-третє, у встановлених законом виключних випадках ця діяльність здійснюється компетентними державними органами.

Оціночні категорії у речовому праві представлені імперативними нормами, оскільки норми, що містять оціночне правило поведінки, мають наказовий характер, передбачають для учасника правовідношення необхідність діяти певним чином. Водночас, зміст оціночної норми передбачає можливість вибору прав та обов'язків в залежності від сукупності обставин, в яких норма права буде застосована. Останнє свідчить і про наявність диспозитивних начал у змісті оціночної норми.

У речовому праві оціночні поняття дозволяють визначити зовнішні межі змісту права власності. 3 одного боку, вони визначають міру можливої поведінки власника, що виражається у повноваженнях володіти, користуватися і розпоряджатися річчю. Їх функціональне призначення полягає у конкретизації наявних дозволів, в накладенні заборон i додаткових обов'язків стосовно майна власника в межах, необхідних i достатніх для досягнення найбільш значущих соціальних цілей. Ці заборони конкретизуються, наприклад у положеннях ч. 5 ст. 319 Цивільного кодексу України (далі - ЦК України) [3]. 3 іншого - вони являються внутрішньою межею розсуду при визначенні змісту конкретного оціночного поняття у речовому праві в процесі застосування правової норми.

Механізм регулятивного впливу оціночних понять зобов'язального права здійснюється лише тоді, коли суб'єктивне право використовується на власний розсуд суб'єкта правозастосування. Це право формується 52 
в межах окреслених нормами об'єктивного цивільного права. Особливістю застосування оціночних понять зобов'язального права $\epsilon$ те, що переважна більшість відносних цивільних правовідносин характеризується наявністю прав та обов'язків у обох сторін зобов'язання. Сторони в таких зобов'язаннях мають більше свободи у встановленні меж при визначенні змісту та конкретизації оціночних понять у кожному випадку, незалежно від існуючої судової практики, звичаїв ділового обороту тощо. Крім того, вони самостійно формують зміст відповідного оціночного поняття під час здійснення суб'єктивних прав, передбачених нормами зобов'язального права.

Разом $з$ тим, визначення меж можливого і належного в оціночних поняттях як сторонами договору, так i судовими органами має виходити не лише з букви, але і духу закону, як джерела цивільного права, що має найвищу юридичну силу.

Найбільш доцільною формою застосування норм, які містять оціночні поняття $є$ договір. В межах цивільно-правового договору можлива об'єктивація таких моральних i правових імперативів, як справедливість, добросовісність і розумність, правова природа яких також містить елементи оцінки, що дозволяє віднести їх до оціночних понять цивільного права.

У разі застосування цивільно-правової норми з оціночним поняттям «добросовісність» необхідно виходити із сукупності суб'єктивних та об'єктивних елементів. Якщо це зобов'язальні правовідносини, об'єктивний елемент добросовісності полягає у необхідності забезпечення балансу інтересів сторін, кожна 3 яких може розраховувати на таку поведінку від іншої сторони, що відповідає вимогам закону i договору; такої поведінки, яку б інша сторона могла 6 i повинна була б схвалити. В суб'єктивному розумінні - це чесність, свідомість, щирість у виконанні цивільно-правових зобов'язань.

У речових правовідносинах добросовісність у об'єктивному розумінні також передбачає забезпечення балансу інтересів учасників, але полягає у наявності законних підстав виникнення права, відкритості інформації про це для відносно невизначеного кола осіб. У суб'єктивному ж - це обізнаність особи щодо своїх дій, а саме незнання про незаконність своїх дій з придбання майна.

Незважаючи на те, що оціночні поняття в цивільному праві відносно визначені, і на перший погляд може здатися їх другорядність та певна залежність від понять абсолютно визначених, оціночні поняття $\epsilon$ обов’язковими при кваліфікації поведінки суб'єктів. I найкраще саме судова практика розкриває зміст цивільно-правових оціночних понять, виробляє єдину лінію їх застосування, встановлює межі, визначає стандарти оціночних понять. 


\title{
Література:
}

1. Бару М. И. Оценочные понятия в трудовом законодательстве. Советское государство и право.1970. № 7. С. 104-108.

2. Богданович С.П. Оценочные понятия в вещном и обязательственном праве : автореф. дис. ... канд. юрид. наук : 12.00.03. Краснодар, 2012. $28 \mathrm{c}$.

3. Цивільний кодекс України від 16.01.2003. № 435-IV. Дата оновлення: 28.10.2021. URL: https://zakon.rada.gov.ua/laws/show/ 435-15\#Text (дата звернення: 24.12.2021).

DOI https://doi.org/10.30525/978-9934-26-179-4-13

\section{TECHNOLOGY TRANSFER AGREEMENTS IN THE SYSTEM OF INTELLECTUAL PROPERTY AGREEMENTS}

\author{
Dmytrenko V. V. \\ Candidate of Science of Law,
}

Senior Lecturer at the Department of Intellectual Property and Private Law

National Technical University of Ukraine

"Igor Sikorsky Kyiv Polytechnic Institute"

Kyiv, Ukraine

In the field of intellectual property, such terms as "technology transfer" and "technology transfer agreements" are often used. The phrase "technology transfer agreements" is of certain interest, since such agreements are not mentioned in the Civil Code and Commercial Code of Ukraine, in any special laws of Ukraine related to intellectual property. Instead, in the Law of Ukraine "On State Regulation of Activity in the Sphere of Transfer of Technologies", Section IV is dedicated to such agreements. Article 1 of this Law [1] states that under technology transfer agreements, people transfer economic rights to a technology or its components fully or partially, while the object of technology may be objects of intellectual property rights. Article 20 of this Law [1] stipulates about the conclusion of intellectual property rights agreements when a technology is transferred, including the terms for entering into technology transfer agreements prescribed by law. It is also stipulated that along with the technology transfer agreements, the following agreements may be concluded: warranty agreements (for the persons transferring the technology, 